Members. (12) Argentina, Bolivia, Brazil, Chile, Colombia, Cuba, Ecuador, Mexico, Paraguay, Peru, Uruguay and Venezuela.

Observers. (28) Andean Development Corporation (CAF), China, Commission of the European Communities, Costa Rica, Dominican Republic, El Salvador, Guatemala, Honduras, Ibero-American General Secretariat (SEGIB), Inter-American Development Bank, Inter-American Institute for Cooperation on Agriculture (IICA), Italy, Japan, South Korea, Latin American Economic System (SELA), Nicaragua, Organization of American States (OAS), Pan American Health Organization (PAHO), Panama, Portugal, Romania, Russia, Spain, Switzerland, Ukraine, UN Development Programme, UN Economic Commission for Latin America and the Caribbean (ECLAC), World Health Organization (WHO).

Official languages: Portuguese, Spanish.

Headquarters: Calle Cebollatí 1461, Casilla de Correos 20005, 11200 Montevideo, Uruguay.

Website: http://www.aladi.org

Secretary-General: Hugo Saguier Caballero (Paraguay).

\section{Latin American Reserve Fund}

Established in 1991 as successor to the Andean Reserve Fund, the Latin American Reserve Fund assists in correcting payment imbalances through loans with terms of up to four years and guarantees extended to members, to co-ordinate their monetary, exchange and financial policies and to promote the liberalization of trade and payments in the Andean sub-region.

Members. Bolivia, Colombia, Costa Rica, Ecuador, Peru, Uruguay, Venezuela.

Official language: Spanish.

Headquarters: Edificio Banco de Occidente, Carrera 13, No.

27-47, Piso 10, Santafe de Bogota, DC, Colombia.

Website: http://www.flar.net

Executive President: Rodrigo Bolaños (Costa Rica).

\section{Organisation of Eastern Caribbean States (OECS)}

Founded in 1981 when seven eastern Caribbean states signed the Treaty of Basseterre agreeing to co-operate with each other to promote unity and solidarity among the members.

Members. Antigua and Barbuda, Dominica, Grenada, Montserrat, St Kitts and Nevis, St Lucia, St Vincent and the Grenadines. The British Virgin Islands and Anguilla have associate membership.

Functions. As set out in the Treaty of Basseterre: to promote cooperation among the member states and to defend their sovereignty and independence; to assist member states in the realization of their obligations and responsibilities to the international community with due regard to the role of international law as a standard of conduct in their relationships; to assist member states in the realization of their obligations and responsibilities to the international community with due regard to the role of international issues; to establish and maintain, where possible, arrangements for joint overseas representation and common services; to pursue these through its respective institutions by discussion of questions of common concern and by agreement on common action.
OECS' work is carried out through the office of the Director General which encompasses: the Legal Unit, Research and Communication Information Services, Functional Co-operation Services, Overseas Diplomatic Mission, Social and Sustainable Development Division, Economic Affairs Division and Corporate Service Division. These oversee the work of a number of specialized institutions, work units and projects in four countries. There is an OECS secretariat in St Lucia, which is comprised of several operating units, responsible for the following functions: Education and Human Resource Development, Export Development Unit, Legal Unit, Environment and Sustainable Development Unit, Pharmaceutical Procurement Service, Social Development Unit and OECS Sports Desk.

Official language: English.

Headquarters: Morne Fortune, PO Box 179, Castries, St Lucia.

Website: http://www.oecs.org

Email: oesec@oecs.org

Director-General: Dr Len Ishmael (St Lucia).

\section{Organization of American States (OAS)}

Origin. On 14 April 1890 representatives of the American republics, meeting in Washington at the First International Conference of American States, established an International Union of American Republics and, as its central office, a Commercial Bureau of American Republics, which later became the Pan-American Union. This international organization's object was to foster mutual understanding and co-operation among the nations of the western hemisphere. This led to the adoption on 30 April 1948 by the Ninth International Conference of American States, at Bogotá, Colombia, of the Charter of the Organization of American States. This co-ordinated the work of all the former independent official entities in the inter-American system and defined their mutual relationships. The Charter of 1948 was subsequently amended by the Protocol of Buenos Aires (1967) and the Protocol of Cartagena de Indias (1985).

Members. Antigua and Barbuda, Argentina, Bahamas, Barbados, Belize, Bolivia, Brazil, Canada, Chile, Colombia, Costa Rica, Cuba (suspended 1962), Dominica, Dominican Republic, Ecuador, El Salvador, Grenada, Guatemala, Guyana, Haiti, Honduras, Jamaica, Mexico, Nicaragua, Panama, Paraguay, Peru, St Kitts and Nevis, St Lucia, St Vincent and the Grenadines, Suriname, Trinidad and Tobago, USA, Uruguay, Venezuela.

Permanent Observers. Algeria, Angola, Armenia, Austria, Azerbaijan, Belgium, Benin, Bosnia and Herzegovina, Bulgaria, China, Croatia, Cyprus, Czech Republic, Denmark, Egypt, Equatorial Guinea, Estonia, EU, Finland, France, Georgia, Germany, Ghana, Greece, Holy See, Hungary, Iceland, India, Ireland, Israel, Italy, Japan, Kazakhstan, South Korea, Latvia, Lebanon, Luxembourg, Morocco, the Netherlands, Nigeria, Norway, Pakistan, Philippines, Poland, Portugal, Qatar, Romania, Russia, Saudi Arabia, Serbia, Slovakia, Slovenia, Spain, Sri Lanka, Sweden, Switzerland, Thailand, Tunisia, Turkey, UK, Ukraine, Vanuatu, Yemen.

Aims and Activities. To strengthen the peace and security of the continent; promote and consolidate representative democracy; promote by co-operative action economic, social and cultural development; and achieve an effective limitation of conventional weapons.

In Sept. 2001 an Inter-American Democratic Charter was adopted, declaring: 'The peoples of the Americas have a right to democracy and their governments have an obligation to 